\title{
New Method for Preparation of Poly(enamino-enaryloxynitriles) and Thermal Properties
}

\author{
Ah-Seon NoH, Ne-Ri GEUM, and Myoung-Seon GoNG ${ }^{\dagger}$ \\ Department of Chemistry, Dankook University, Cheonan, Chungnam 330-714, Korea
}

(Received July 31, 2000; Accepted October 24, 2000)

\begin{abstract}
A kinetic study on enaryloxynitriles via nucleophilic vinylic substitution reactions of various phenol derivatives with 1-chloro-1-phenyl-2,2-dicyanoethene was conducted in the presence of 1,4-diazabicyclo[2,2,2]octane (DABCO). The reaction was applied to solution polymerization of diphenol and diamine derivatives with $p$-bis(1-chloro2,2-dicyanovinyl)benzene, which gave various poly(enamino-enaryloxynitriles) with moderate molecular weights in good yields. Thermal properties such as thermal curing and thermal stability were examined by differential scanning calorimetry and thermogravimetric analysis. The poly(enamino-enaryloxynitriles) showed similar curing to typical polyenaminonitriles and polyenaryloxynitriles.

KEY WORDS Polyenaryloxynitriles / Poly(enamino-enaryloxynitrile) / Thermally Stable Polymers / Dicyanovinyl Group /
\end{abstract}

Early attempt to characterize the behavior of atoms in assembly by a parameter was the concept for electronegativity formulated by L. Pauling. ${ }^{1}$ One powerful electronegativity-enhancing group is the cyano group. The more $\mathrm{C} \equiv \mathrm{N}$ groups a carbon atom bears, the greater is its attraction for electrons. The dicyanomethylidene $\left(=\mathrm{C}(\mathrm{CN})_{2}\right)$ group and carbonyl oxygen atom have similar inductive and resonance effects. The dicyanomethylidene group can be considered structurally equivalent to the carbonyl group in reactions where two functional groups have similar inductive and resonance effects. ${ }^{2,3}$

Many well-known carbonyl group-containing reactions include Fries shift, Friedel-Crafts synthesis and Curtius-analogous rearrangement, which have been shown to closely parallel the dicyanomethylidene group. ${ }^{3} \mathrm{Vi}$ nylic nucleophilic substitution reaction of $2,2-$ dicyanovinyl chloride proceeds by various mechanistic pathways. In most cases, primary nucleophilic attack on the double bond is followed by expulsion of the leaving group via an addition-elimination route. ${ }^{4-11}$

2,2-Dicyanovinyl chloride reacts with amine, in most cases by a two step addition-elimination mechanism, to produce enaminonitrile. ${ }^{12}$ Phenoxide anions are used as nucleophiles for enaryloxynitriles and applied to interfacial polymerization of diphenol derivatives with $p$-bis(1chloro-2,2-dicyanovinyl)benzene to give polyenaryloxynitriles. $^{13-19}$ But phenol itself reacts with dicyanovinyl chloride in the presence of tertiary amine as if the acid chloride reacted with phenol derivatives. 1,4Diazabicyclo[2,2,2] octane (DABCO) catalyzes nucleophilic vinylic substitution reactions of 1-chloro-1phenyl-2,2-dicyanoethene (1) or $p$-bis (chloro-2,2dicyanovinyl)benzene (2) with various phenols to form enaryloxynitriles derivatives. ${ }^{20}$

The authors conducted a kinetic study on reactions of 1 with phenol derivatives in the presence of DABCO and new method for the preparation of poly(enaminoenaryloxynitriles) via nucleophilic vinylic substitution reaction of 2 was established. A study on thermal cur- ablility and stability of new polymers is presented.

\section{EXPERIMENTAL}

\section{Materials and Instruments}

1-Chloro-2,2-dicyanoethene (1) and $p$-bis(1-chloro-2,2dicyanovinyl)benzene (2) were prepared as reported previously. ${ }^{12}$ Phenol, $p$-cresol, $p$-chlorophenol, $p$ nitrophenol, and 1,4-diazabicyclo[2,2,2]octane (Aldrich Chem. Co.) were used without further purification. 4,4'Oxydianiline, bisphenol A, $p$-aminophenol and hydroquinone were used after recrystallization in ethanol. 1,3Bis(4-hydroxyphenoxy)propane (1,3-BHPP), 1,3-bis(4aminophenoxy ) propane (1,3-BAPP ), 1,5-bis ( 4aminophenoxy)pentane (1,5-BAPP) and 1,5-bis (4hydroxyphenoxy)pentane (1,5-BHPP) were prepared by as previously. ${ }^{21} \mathrm{~N}$-Methyl-2-pyrrolidone (NMP) was purified by vacuum distillation after drying by azeotropic distillation with benzene using a Dean-Stark separator.

${ }^{1} \mathrm{H} \mathrm{NMR}$ and ${ }^{13} \mathrm{C}$ NMR spectra were recorded on a Varian Gemini 2000 spectrometer. Fourier transform infrared (FT-IR) spectra were taken on a Midac model M1200 spectrometer. Gas chromatograms were obtained with a Varian Star 3400 gas chromatography (GC). Elemental analysis data were obtained with a Yanaco-MT-3 elemental analyzer. Differential scanning calorimetry (DSC) measurements were performed on a Perkin-Elmer DSC 7 under nitrogen at a heating rate of $10^{\circ} \mathrm{C}$ $\min ^{-1}$. Thermogravimetric analysis (TGA) was carried out using a Shimadzu TGA 50 thermal analyzer at a heating rate of $10^{\circ} \mathrm{C} \mathrm{min}^{-1}$ under nitrogen.

Representative Preparation of 1-Phenoxy-1-phenyl-2,2dicyanoethene (3)

Into a three-necked round-bottomed flask equipped with a dropping funnel, a condenser and nitrogen inlet system, was introduced a solution of phenol $(0.25 \mathrm{~g}, 2.65$ $\mathrm{mmol})$ and DABCO $(0.30 \mathrm{~g}, 2.65 \mathrm{mmol})$ in dry NMP (10 $\mathrm{mL}$ ). After the solution was purged with nitrogen, a solu-

${ }^{\dagger}$ To whom correspondence should be addressed (E-mail: msgong@anseo.dankook.ac.kr). 
tion of $1(0.5 \mathrm{~g}, 2.65 \mathrm{mmol})$ in NMP $(10 \mathrm{~mL})$ was added dropwise at $20^{\circ} \mathrm{C}$ for $5 \mathrm{~min}$. The stirred mixture was heated to $60^{\circ} \mathrm{C}$ and maintained for $24 \mathrm{~h}$. After the reaction mixture was poured into water, the powdery product obtained was filtered and recrystallized in isopropanol. Similar procedures were used to synthesize enaryloxynitriles 4-6.

3: Yield $85 \%$. Mp 139.5-140 $\mathrm{C}$. IR $(\mathrm{KBr}): 3022(\mathrm{C}-\mathrm{H})$, $2219(\mathrm{C} \equiv \mathrm{N}), 1585(\mathrm{C}=\mathrm{C}), 1250-1100(\mathrm{C}-\mathrm{O}) \mathrm{cm}^{-1} .{ }^{1} \mathrm{H}$ $\mathrm{NMR}\left(\mathrm{CDCl}_{3}\right): \delta=7.4-7.7(\mathrm{~m} 5 \mathrm{H}, P h-), 7.0-7.2(\mathrm{~m}, 5 \mathrm{H}$, $-\mathrm{O}-\mathrm{Ph}) .{ }^{13} \mathrm{C} \mathrm{NMR}\left(\mathrm{CDCl}_{3}\right): \delta=71.2\left(=\mathrm{C}(\mathrm{CN})_{2}\right), 111.3$, $113.1(-C \mathrm{~N}), 122.5,128.0,129.6,130.1,132.8,151.5$ (aromatic $C$ 's), $180.7\left(=C-\mathrm{O}^{-}\right.$). Anal. Calcd for $\mathrm{C}_{16} \mathrm{H}_{10^{-}}$ $\mathrm{N}_{2} \mathrm{O}: \mathrm{C}, 78.05 \%$; H, 4.07\%; N, $11.38 \%$. Found: C, 77.89\%; $\mathrm{H}, 4.04 \%$; N, $11.27 \%$.

4: Yield 95\%. Mp $134^{\circ} \mathrm{C}$. IR (KBr): 3022 (aromatic C$\mathrm{H}), 2960$ (aliphatic $\mathrm{C}-\mathrm{H}), 2221(\mathrm{C} \equiv \mathrm{N}), 1580(\mathrm{C}=\mathrm{C})$, 1250-1120 (C-O) $\mathrm{cm}^{-1} .{ }^{1} \mathrm{H}$ NMR (dimethyl sulfoxide (DMSO)- $d_{6}$ ): $\delta=7.5(\mathrm{~m}, 5 \mathrm{H}, P h-), 7.1\left(\mathrm{~m}, 4 \mathrm{H}^{\prime}-\mathrm{Ph}-\mathrm{CH}_{3}\right.$ ), $2.3\left(\mathrm{~s}, 3 \mathrm{H}, \mathrm{CH}_{3}-\mathrm{Ph}-\right)$. Anal. Calcd for $\mathrm{C}_{17} \mathrm{H}_{12} \mathrm{~N}_{2} \mathrm{O}: \mathrm{C}$, 78.46\%; H, 4.62\%; N, 10.77\%. Found: C, 78.29\%; $\mathrm{H}$, $4.64 \%$; N, $10.67 \%$.

5: Yield $75 \%$. Mp $120^{\circ} \mathrm{C}$. IR $(\mathrm{KBr}): 3022(\mathrm{C}-\mathrm{H}), 2221(\mathrm{C}$ $\equiv \mathrm{N}), 1580(\mathrm{C}=\mathrm{C}), 1250-1120(\mathrm{C}-\mathrm{O}) \mathrm{cm}^{-1} .{ }^{1} \mathrm{H}$ NMR $\left(\mathrm{DMSO}-d_{6}\right): \delta=8.3-7.8(\mathrm{~m}, 5 \mathrm{H}, \mathrm{Ph}-), 7.1-7.4(\mathrm{~m}, 4 \mathrm{H}$, $\mathrm{O}-\mathrm{Ph}-\mathrm{Cl}$ ). Anal. Calcd for $\mathrm{C}_{16} \mathrm{H}_{9} \mathrm{~N}_{2} \mathrm{ClO}: \mathrm{C}, 68.45 \% ; \mathrm{H}$, $3.21 \%$; N, $12.66 \%$. Found: C, 68.25\%; H, 3.19\%; N, $12.56 \%$.

6: Yield 68\%. Mp $167^{\circ} \mathrm{C}$. IR (KBr): $3022(\mathrm{C}-\mathrm{H}), 2221(\mathrm{C}$ $\equiv \mathrm{N}), 1580(\mathrm{C}=\mathrm{C}), 1552(\mathrm{~N}=\mathrm{O}), 1280-1110(\mathrm{~N}-\mathrm{O}, \mathrm{C}-\mathrm{O}$, and $\mathrm{C}-\mathrm{N}) \mathrm{cm}^{-1} \cdot{ }^{1} \mathrm{H} \mathrm{NMR}\left(\mathrm{CDCl}_{3}\right): \delta=7.5-7.8(\mathrm{~m}, 5 \mathrm{H}$, $P h-), 8.1-8.4\left(\mathrm{~m}, 4 \mathrm{H},-\mathrm{Ph}-\mathrm{NO}_{2}\right)$. Anal. Calcd for $\mathrm{C}_{16} \mathrm{H}_{9^{-}}$ $\mathrm{N}_{3} \mathrm{O}_{3}: \mathrm{C}, 65.98 \% ; \mathrm{H}, 3.09 \% ; \mathrm{N}, 14.43 \%$. Found: C, $65.84 \% ; \mathrm{H}, 3.02 \% ; \mathrm{N}, 14.29 \%$.

\section{Kinetics}

The reactions were monitored by the appearance of enaryloxynitriles using a Varian Star 3400 gas chromatography (GC). All reactions were performed under third-order conditions in which DABCO concentrations was the same as that of phenol. Phenol solution was prepared by dissolving equimolecular amounts of phenol and $\mathrm{DABCO}$ in NMP. Substrate-containing solutions were prepared by dissolving 1 in NMP. All solutions were prepared fresh just before use under a nitrogen atmosphere and transferred by micro-syringe to GC.

Preparation of 1-Phenyl-2,2-dicyanovinyl-1-[p-1-phenyl2,2-dicyanovinylamino) phenoxy]ethene (7)

In a three-necked round-bottomed flask equipped with a dropping funnel, condenser and nitrogen inlet system, was placed a solution of aminophenol $(0.36 \mathrm{~g}, 3.3 \mathrm{mmol})$ and DABCO $(0.56 \mathrm{~g}, 5.0 \mathrm{mmol})$ in dry NMP $(10 \mathrm{~mL})$. After the solution was purged with nitrogen, a solution of 1 $(1.25 \mathrm{~g}, 6.6 \mathrm{mmol})$ in NMP $(10 \mathrm{~mL})$ was added dropwise at $20^{\circ} \mathrm{C}$ for $5 \mathrm{~min}$. The stirred mixture was heated to $60^{\circ} \mathrm{C}$ and maintained for $24 \mathrm{~h}$. After the reaction mixture was poured into water, the powdery product was collected by filtration and washed with water/isopropanol $(1 / 1, v / v)$. The crude product was recrystallized in acetonitrile to give pale yellow crystals and dried in vacuo at $50^{\circ} \mathrm{C}$ for $12 \mathrm{~h}$.

7: Yield $88 \%$. Mp $202^{\circ} \mathrm{C}$. IR (KBr): $3350(\mathrm{~N}-\mathrm{H}), 3180$ (aromatic $\mathrm{C}-\mathrm{H}), 2220(\mathrm{C} \equiv \mathrm{N}), 1578(\mathrm{C}=\mathrm{C}), 1260-1120$ $(\mathrm{C}-\mathrm{O}$ and $\mathrm{C}-\mathrm{N}) \mathrm{cm}^{-1} .{ }^{1} \mathrm{H} \mathrm{NMR}\left(\mathrm{CDCl}_{3}\right): \delta=9.8(\mathrm{br}, 1 \mathrm{H}$, $-\mathrm{NH}-$ ), 7.6 (m, 10H, $2-\mathrm{Ph}$ ), 7.2-6.8 (m, 4H, -NH-PhO-). Anal. Calcd for $\mathrm{C}_{26} \mathrm{H}_{15} \mathrm{~N}_{5} \mathrm{O}_{1}$ : C, 75.54; $\mathrm{H} 3.63 ; \mathrm{N}$, 16.95. Found: C, 74.45; H, 3.69; N, 17.49.

\section{Representative Polymerization of $\mathbf{2}$ with Diphenols and Diamines}

Into a three-necked round-bottomed flask equipped with a dropping funnel, a condenser and a nitrogen inlet system, was introduced solution of bisphenol A (1.50 g, $6.6 \mathrm{mmol})$ and DABCO $(0.74 \mathrm{~g}, 6.6 \mathrm{mmol})$ in dry NMP $(10 \mathrm{~mL})$. After the solution was purged with nitrogen, a solution of $2(2.0 \mathrm{~g}, 6.6 \mathrm{mmol})$ in NMP $(10 \mathrm{~mL})$ was added dropwise at $20^{\circ} \mathrm{C}$ for $5 \mathrm{~min}$. The stirred mixture was heated to $60^{\circ} \mathrm{C}$ and maintained for $24 \mathrm{~h}$. After the reaction mixture was poured into water, the powdery polymer was collected by filtration and washed with methanol/water (1/1, v/v). Tetrahydrofuran (THF) solution was reprecipitated in hexane to produce a yellow powdery polymer. Similar procedures were applied to synthesize polyenaryloxynitriles $\mathbf{9 - 1 0}$ and poly(enamino-enaryloxynitriles) 11-14.

8: Yield 86\%. IR (KBr): $3050(\mathrm{C}-\mathrm{H}), 2220(\mathrm{C} \equiv \mathrm{N}), 1580$ $(\mathrm{C}=\mathrm{C}), 1330,1250-1110(\mathrm{C}-\mathrm{O}) \mathrm{cm}^{-1} \cdot{ }^{1} \mathrm{H}$ NMR (DMSO$\left.d_{6}\right): \delta=7.5(\mathrm{~s}, 4 \mathrm{H}$, aromatic $H$ 's $), 6.8-7.2(\mathrm{~m}, 8 \mathrm{H}$, aromatic H's in bisphenol A), $1.4\left(\mathrm{~s}, 6 \mathrm{H}, 2-\mathrm{CH}_{3}\right) .{ }^{13} \mathrm{C} \mathrm{NMR}$ $\left(\mathrm{DMSO}-d_{6}+\mathrm{CDCl}_{3}\right): \delta=30.6,42.6,72.5,110.3,112.2$, $114.9,119.3,127.6,128.6,130.6,148.8,151.7,178.0$. Anal. Calcd for $\mathrm{C}_{29} \mathrm{H}_{18} \mathrm{~N}_{4} \mathrm{O}_{2}: \mathrm{C}, 76.65 \% ; \mathrm{H}, 3.96 \% ; \mathrm{N}$, 12.33\%. Found: C, 76.98\%; H, 4.01\%; N, $12.29 \%$.

9: Yield 92\%. IR (KBr): $3050(\mathrm{C}-\mathrm{H}), 2220(\mathrm{C} \equiv \mathrm{N}), 1580$ $(\mathrm{C}=\mathrm{C}), 1330,1250-1110(\mathrm{C}-\mathrm{O}) \mathrm{cm}^{-1} .{ }^{1} \mathrm{H}$ NMR (DMSO$\left.d_{6}+\mathrm{CDCl}_{3}\right): \delta=7.5$ (br, $4 \mathrm{H}$, aromatic $H$ 's in 2 ), $6.8-7.2$ $(\mathrm{m}, 8 \mathrm{H}, 1 / 2$ aromatic $H$ 's in bisphenol $\mathrm{A}$ and $1 / 2$ aromatic $H^{\prime}$ 's in diphenol), 3.8 (br, $\left.2 \mathrm{H}, 1 / 2-\mathrm{OCH}_{2} \mathrm{CH}_{2} \mathrm{CH}_{2} \mathrm{O}^{-}\right), 1.2$ $-1.8\left(\mathrm{~m}, 3 \mathrm{H}, 1 / 2-\mathrm{OCH}_{2} \mathrm{CH}_{2} \mathrm{CH}_{2} \mathrm{O}^{-}\right), 1.4(\mathrm{~s}, 3 \mathrm{H}, 1 / 22-$ $\mathrm{CH}_{3}$ ). Anal. Calcd for $\mathrm{C}_{29} \mathrm{H}_{18} \mathrm{~N}_{4} \mathrm{O}_{3}$ : C, 70.04\%; $\mathrm{H}, 3.83 \%$; $\mathrm{N}, 11.92 \%$. Found: C, $70.28 \%$; H, $4.02 \%$; N $11.54 \%$.

10: Yield 94\%. IR (KBr): $3355(\mathrm{~N}-\mathrm{H}), 3125,2950$ (aromatic and aliphatic $\mathrm{C}-\mathrm{H}), 2220(\mathrm{C} \equiv \mathrm{N}), 1580(\mathrm{C}=\mathrm{C})$, 1330, 1250-1105 (C-N and $\mathrm{C}-\mathrm{O}) \quad \mathrm{cm}^{-1} \cdot{ }^{1} \mathrm{H} \mathrm{NMR}$ $\left(\mathrm{DMSO}-d_{6}+\mathrm{CDCl}_{3}\right): \delta=9.6(\mathrm{br}, \mathrm{N}-\mathrm{H}), 7.5$ (br, $4 \mathrm{H}$, aromatic $H^{\prime}$ 's in 2), 6.8-7.2 (m, 1/2 aromatic H's in hydroquinone and 1/2 2 aromatic $H$ 's in diphenol), $3.8(\mathrm{~m}, 2 \mathrm{H}$, $\left.1 / 2-\mathrm{OCH}_{2} \mathrm{CH}_{2} \mathrm{CH}_{2} \mathrm{CH}_{2} \mathrm{CH}_{2} \mathrm{O}^{-}\right), 1.2-1.8(\mathrm{~m}, 3 \mathrm{H}, 1 / 2$ $-\mathrm{OCH}_{2} \mathrm{CH}_{2} \mathrm{CH}_{2} \mathrm{CH}_{2} \mathrm{CH}_{2} \mathrm{O}-$ ). Anal. Calcd for $\mathrm{C}_{30.5} \mathrm{H}_{16} \mathrm{~N}_{5}$ $\mathrm{O}_{2}$ : C, $75.00 \% ; \mathrm{H}, 3.72 \%$; N $12.77 \%$. Found: C, $74.28 \%$; $\mathrm{H}, 3.81 \%$; N, $12.54 \%$.

11: Yield 91\%. IR (KBr): $3550(\mathrm{~N}-\mathrm{H}), 3050,2860$ (aromatic and aliphatic $\mathrm{C}-\mathrm{H}), 2220(\mathrm{C} \equiv \mathrm{N}), 1578(\mathrm{C}=\mathrm{C})$, $1330, \quad 1250-1110(\mathrm{C}-\mathrm{N}$ and $\mathrm{C}-\mathrm{O}) \mathrm{cm}^{-1} \cdot{ }^{1} \mathrm{H} \mathrm{NMR}$ $\left(\mathrm{DMSO}-d_{6}+\mathrm{CDCl}_{3}\right): \delta=9.6(\mathrm{br}, \mathrm{N}-\mathrm{H}), 7.5(\mathrm{br}, 4 \mathrm{H}$, aromatic H's in 2), 6.8-7.2 (m, 1/2 aromatic H's in bisphenol $\mathrm{A}$ and $1 / 2$ aromatic $H$ 's in ODA), $1.4(\mathrm{~s}, 3 \mathrm{H}, 1 / 2$ $2-\mathrm{CH}_{3}$ ). Anal. Calcd for $\mathrm{C}_{27.5} \mathrm{H}_{16} \mathrm{~N}_{5} \mathrm{O}_{1.5}: \mathrm{C}, 75.00 \% ; \mathrm{H}$, $3.64 \%$; N, $15.91 \%$. Found: C, $74.56 \% ; \mathrm{H}, 3.25 \%$; , $15.63 \%$.

12: Yield 96\%. IR (KBr): $3050(\mathrm{C}-\mathrm{H}), 2220(\mathrm{C} \equiv \mathrm{N})$, $1580(\mathrm{C}=\mathrm{C}), 1330,1250-1110(\mathrm{C}-\mathrm{O}) \mathrm{cm}^{-1} .{ }^{1} \mathrm{H} \mathrm{NMR}$ (DMSO- $d_{6}+\mathrm{CDCl}_{3}$ ): $\delta=7.5$ (br, $4 \mathrm{H}$, aromatic $H$ 's in 2 ), 6.8-7.2 (m, 8H, 1/2 aromatic $H^{\prime}$ 's in 4,4'-thiodiphenol and 1/2 aromatic $H^{\prime}$ 's in diphenol), 3.8 (br, $2 \mathrm{H}, 1 / 2-\mathrm{OCH}_{2}$ - 
$\mathrm{CH}_{2} \mathrm{CH}_{2} \mathrm{O}^{-}$), $1.2-1.8$ (m, 3H, $1 / 2-\mathrm{OCH}_{2} \mathrm{CH}_{2} \mathrm{CH}_{2} \mathrm{O}^{-}$), 1.4 (s, 3H, 1/2 $2-\mathrm{CH}_{3}$ ). Anal. Calcd for $\mathrm{C}_{33.5} \mathrm{H}_{18} \mathrm{~N}_{5} \mathrm{O}_{2.5}$ : C, $75.85 \%$; H, 3.40\%; N, 13.21\%. Found: C, 75.27\%; H, $3.34 \% ; \mathrm{N}, 12.76 \%$.

13: Yield $89 \%$. IR (KBr): $3380(\mathrm{~N}-\mathrm{H}), 3050-2870$ (aromatic and aliphatic $\mathrm{C}-\mathrm{H}), 2218(\mathrm{C} \equiv \mathrm{N}), 1578(\mathrm{C}=\mathrm{C})$, 1330, $1260-1100 \quad(\mathrm{C}-\mathrm{N}$ and $\mathrm{C}-\mathrm{O}) \mathrm{cm}^{-1} \cdot{ }^{1} \mathrm{H} \mathrm{NMR}$ $\left(\mathrm{DMSO}^{-} d_{6}+\mathrm{CDCl}_{3}\right): \delta=9.4(\mathrm{br}, \mathrm{N}-\mathrm{H}), 7.6(\mathrm{br}, 4 \mathrm{H}$, aromatic H's in 2), 6.8-7.2 (m, $8 \mathrm{H}, 1 / 2$ aromatic $H^{\prime}$ 's in ODA and $1 / 2$ aromatic $H^{\prime} s$ in diphenol), $3.8(\mathrm{br}, 1 / 2$ $\left.-\mathrm{OCH}_{2} \mathrm{CH}_{2} \mathrm{CH}_{2} \mathrm{CH}_{2} \mathrm{CH}_{2} \mathrm{O}^{-}\right), 1.2-1.8\left(\mathrm{~m}, 3 \mathrm{H}, 1 / 2 \mathrm{OCH}_{2^{-}}\right.$ $\mathrm{CH}_{2} \mathrm{CH}_{2} \mathrm{CH}_{2} \mathrm{CH}_{2} \mathrm{O}^{-}$). Anal. Calcd for $\mathrm{C}_{20} \mathrm{H}_{9} \mathrm{~N}_{5} \mathrm{O}$ : C, 71.64\%; H, 2.69\%; N, 20.90\%. Found: C, 71.29\%; $\mathrm{H}$, $2.64 \% ; \mathrm{N}, 20.67 \%$.

\section{RESULTS AND DISCUSSION}

Enaryloxynitriles and polyenaryloxynitriles ware obtainable by a two-phase solvent system using a phase transfer catalyst. ${ }^{13}$ In this study, various enaryloxynitriles were prepared by reactions of 1 with phenol derivatives in the presence of DABCO. After $24 \mathrm{~h}$, good yields of enaryloxynitriles were obtained. The results and conditions of preparation of various enaryloxynitriles are summarized in Table I.

In ${ }^{1} \mathrm{H}$ NMR spectra, phenyl protons in $\mathbf{3}$ appeared as a multiplet centered at $7.5 \mathrm{ppm}$, whereas those of phenol were present as a multiplet at $7.2 \mathrm{ppm}$. Enaryloxynitriles derived from other phenol derivatives such as $p$ cresol showed a singlet at $2.4 \mathrm{ppm}$ corresponding to methyl group. Reactivity of various phenols to 1 varied according to $\mathrm{p} K_{\mathrm{a}}$ of the corresponding phenol. In the case of $p$-cresol with $\mathrm{p} K_{\mathrm{a}} 10.26$, the reaction proceeded rapidly to give 1-(4-methylphenoxy)-1-phenyl-2,2dicyanoethene (4) in good yield because of electron donation by the substituent at the para-position. $p$ Chlorophenol proceeded at a slower rate.

The rates of DABCO catalyzed reactions between $\mathbf{1}$ and phenol derivatives were measured in NMP at $60^{\circ} \mathrm{C}$ by gas chromatography. The reaction of phenol with $\mathbf{1}$ carrying sluggish leaving group involves a third-order term, first order each in the vinyl halide, phenol and $\mathrm{DABCO}$. The initially formed anion is followed by expulsion of chloride anion. The third-order rate coefficient for the product is given by the following equation according to Scheme 1.

$$
k_{\mathrm{obs}}=\frac{k_{1}[\mathbf{1}][\text { phenol] }[\mathrm{DABCO}]}{\left(k_{-1}+k_{2}\right)[\mathbf{1}+\text { phenoxide }]\left[\mathrm{DABCO}_{\mathrm{salt}}\right]}
$$

When $k_{2} \gg k_{-1}$, and $k_{\mathrm{obs}}$, is given by the equation $k_{\mathrm{obs}}=$ $k_{1}$. Comparison of our data with measurement of the same reaction using substituted phenolic compounds, electron-donating group at para-position increased the reactivity of the phenol derivative to 1. Experimental conditions and third-order rate constant for the reaction of $\mathbf{1}$ with phenol derivatives are summarized in Table II and Figure 1.

Displacement of the vinylic halogen by four phenols was followed by gas chromatographically in NMP by observing the integration of the product enaryloxynitriles. $\operatorname{Br} \phi$ nsted plots of $\log k_{\text {obs }}$ against the $\mathrm{p} K_{\mathrm{a}}$ of the para-
Table I. Results of reaction of 1 with phenol derivatives

\begin{tabular}{ccrc}
\hline $\begin{array}{c}\text { Phenol } \\
\text { derivatives }\end{array}$ & Substituent $\mathrm{a}^{\mathrm{a}}$ & $\mathrm{p} K_{\mathrm{a}}$ & ${\text { Yield } / \%^{\mathrm{b}}}^{\mathrm{m}}$ \\
\hline $\mathbf{3}$ & $\mathrm{H}$ & 9.99 & 85 \\
$\mathbf{4}$ & $p-\mathrm{Me}$ & 10.26 & 95 \\
$\mathbf{5}$ & $p-\mathrm{Cl}$ & 9.43 & 75 \\
$\mathbf{6}$ & $p-\mathrm{NO}_{2}$ & 7.17 & 68 \\
\hline
\end{tabular}

${ }^{\mathrm{a}}$ Para-position of phenol derivative. ${ }^{\mathrm{b}}$ Yields determined gravimetrically after recrystallization.

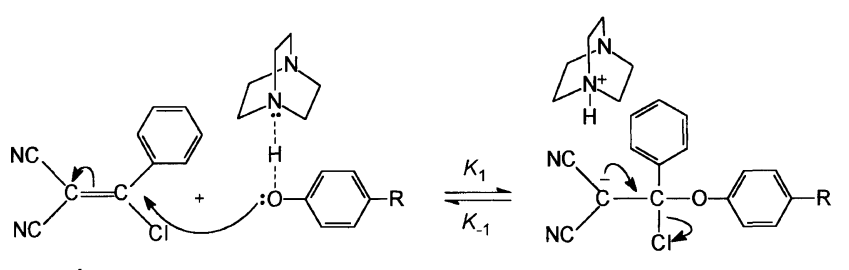

1

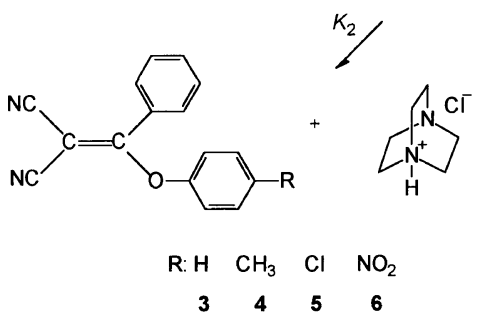

Scheme 1.

Table II. Experimental conditions and third order rate constants for reactions of 1 with phenol derivatives in the presence of DABCO in NMP

\begin{tabular}{ccccc}
\hline $\mathrm{X}$ & {$[\mathbf{1}] / 10^{-3}$} & {$[\mathrm{X}-\mathrm{PhOH}] / 10^{-3}$} & {$[\mathrm{DABCO}] / 10^{-3}$} & $k_{\mathrm{obs}} / 10^{-6}$ \\
\hline$p-\mathrm{Me}$ & 4.82 & $4.82-24.11$ & $4.82-24.11$ & $1.91-9.76$ \\
$\mathrm{H}$ & 5.00 & $5.00-24.53$ & $5.00-24.53$ & $1.21-6.02$ \\
$p-\mathrm{Cl}$ & 5.21 & $5.21-26.05$ & $5.51-26.05$ & $0.98-5.05$ \\
$p-\mathrm{NO}_{2}$ & 5.54 & $5.61-27.50$ & $5.61-27.50$ & $0.15-0.81$ \\
\hline
\end{tabular}

substituted phenols are shown in Figure 2. Such linear $\mathrm{Br} \phi$ nsted-type plots suggest that there is no mechanism change for the present nucleophilic reactions of 1 with phenols. The slope $\log k_{\text {obs }} / \mathrm{p} K_{\mathrm{a}}$ is 0.356 .

Prior to the synthesis of poly (enaminoenaryloxynitriles), model enamino-enaryloxynitriles compound 1-phenyl-2,2-dicyanovinyl-1-[p-(1-phenyl-2,2dicyanovinyl amino)phenoxy]ethene (7) was prepared by reaction of 1 with $p$-aminophenol using DABCO as illustrated in Scheme 2.

Scheme 3 outlines the solution polymerization of 2 with aromatic diols and aromatic diamines in the presence of DABCO in NMP solution.

The results of polymerization of 2 with diphenols and diamines are summarized in Table III. The polymers obtained here were identified as polyenaryloxynitriles, and poly(enamino-enaryloxynitriles) by comparing IR and NMR spectra with those of model compounds $\mathbf{3}$ and $\mathbf{7}$. In the IR spectrum of polyenaryloxynitriles $\mathbf{8}$ and $\mathbf{9}$, characteristic absorption bands of $\mathrm{C} \equiv \mathrm{N}, \mathrm{C}=\mathrm{C}$, and $\mathrm{C}-\mathrm{O}$ were exhibited at 2220,1580 , and $1250-1100 \mathrm{~cm}^{-1}$, respectively. The ${ }^{1} \mathrm{H}$ NMR spectrum of polymers 8 and $\mathbf{9}$ showed multiplets at $6.8-7.2 \mathrm{ppm}$ assignable to aromatic protons of diphenol moiety and a broad singlet 


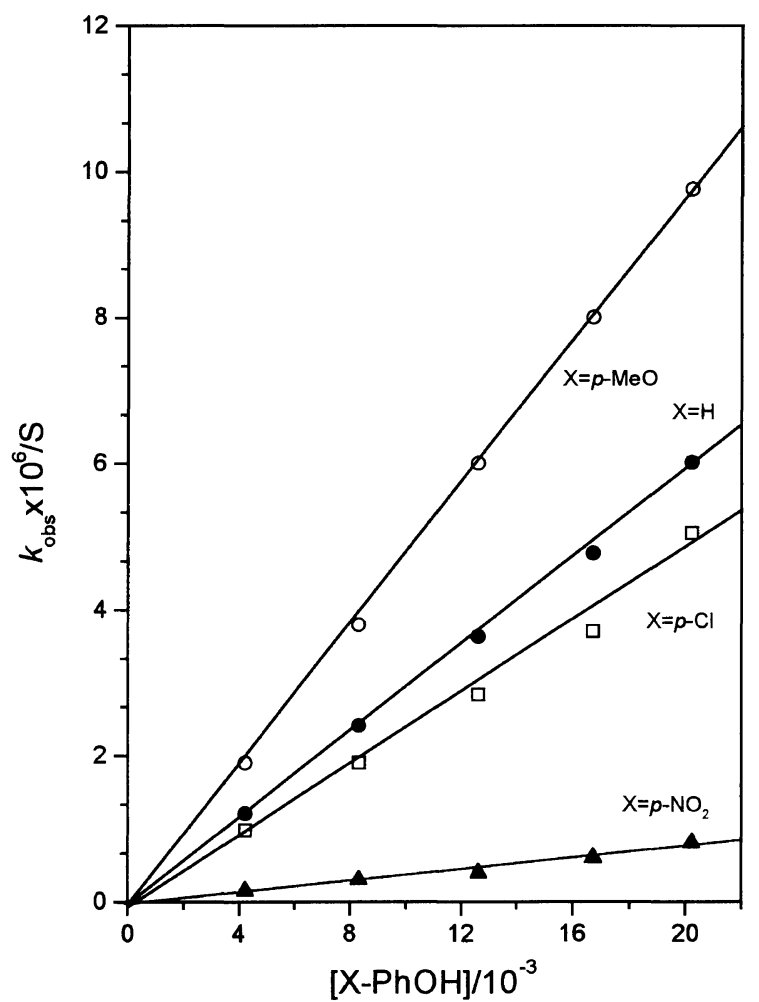

Figure 1. Plots showing dependence of $k_{\mathrm{obs}}$ on concentrations of nucleophiles for reactions of 1-chloro-phenyl-2,2-dicyanoethene with phenol derivatives in the presence of DABCO in NMP.

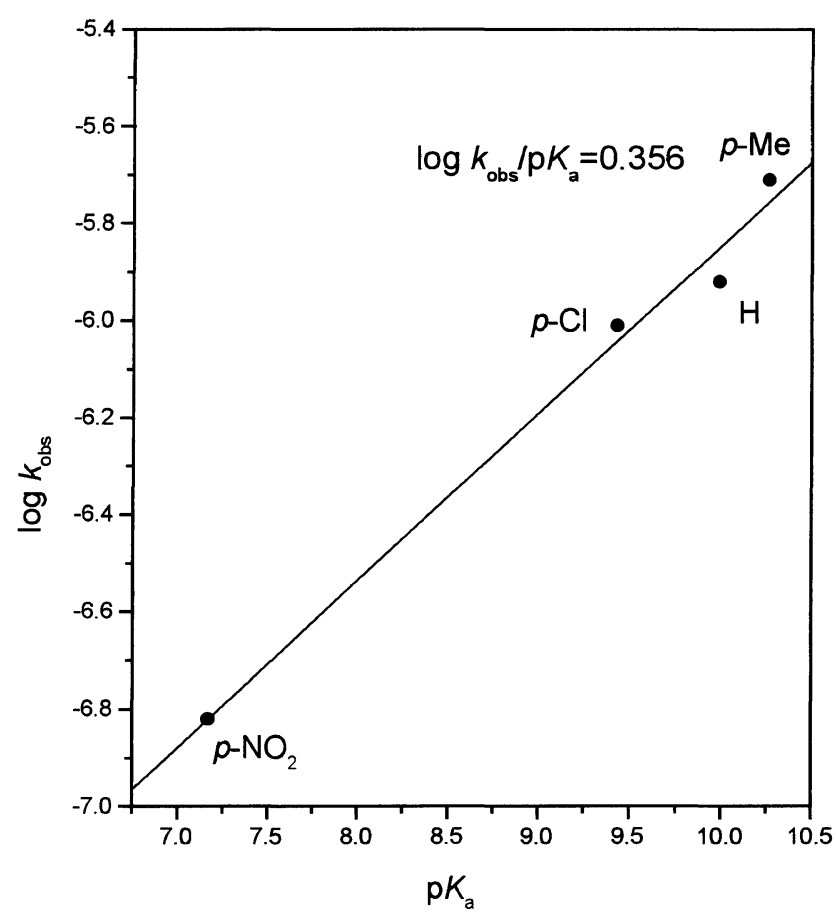

Figure 2. Bronsted-type plots for reactions of 1 and phenol derivatives in the presence of $\mathrm{DABCO}$ in NMP at $60^{\circ} \mathrm{C}$.

around $7.6 \mathrm{ppm}$ attributable to the fragment of $\mathbf{2}$. Aliphatic units appeared at $1.4 \mathrm{ppm}, 1.2-1.8$ and $3.8 \mathrm{ppm}$ corresponding to $-\mathrm{C}\left(\mathrm{CH}_{3}\right)_{2}-,-\mathrm{O}^{-} \mathrm{CH}_{2} \mathrm{CH}_{2} \mathrm{CH}_{2} \mathrm{O}^{-}$and - $\mathrm{O}^{-}$ $\mathrm{CH}_{2} \mathrm{CH}_{2} \mathrm{CH}_{2} \mathrm{O}^{-}$, respectively. Polyenaryloxynitriles may thus be synthesized via solution polymerization tech-<smiles>N#CC(C#N)=C(Cl)c1ccccc1</smiles><smiles>N#CC(C#N)=C(Nc1ccc(OC(=C(C#N)C#N)c2ccccc2)cc1)c1ccccc1</smiles>

Scheme 2.<smiles>N#CC(C#N)=C(Cl)c1ccc(C(Cl)(C#N)C#N)cc1</smiles><smiles>CC(C)(C)C(=C(C#N)C#N)c1ccc(/C=C(\C#N)C(C)(C)C)cc1</smiles><smiles>CC(C)(c1ccc(O)cc1)c1ccc(O)cc1</smiles><smiles>Oc1ccc(OCCOc2ccc(O)cc2)cc1</smiles><smiles>Oc1ccc(O)cc1</smiles><smiles>Nc1ccc(Oc2ccc(N)cc2)cc1</smiles><smiles>Nc1ccc(OCCOC(=O)c2ccc(N)cc2)cc1</smiles>

IV<smiles>[NH3+]C1C=CC(O)=CC1</smiles>

vi
Scheme 3.

niques. Elemental analysis supported the formation of the polymers and matched well with calculated data. The results of elemental analysis for the resulting copolymer prove that a constituent ratio incorporated in polymer sequence to that of amine units is approximately $1: 1$ as expected.

Copolymerization reactions of 2 with aromatic phenol and diamine were conducted in NMP solution to give the poly(enamino-enaryloxynitriles) 10-13. Reaction of 2 with equivalent quantity of aromatic diphenol and diamine at $60^{\circ} \mathrm{C}$ was rapid and led to $89-94 \%$ yields of poly-(enamino-enaryloxynitriles).

In the IR spectra, all polymers showed characteristic absorption bands around 3350,2220 , and $1580 \mathrm{~cm}^{-1}$ corresponding to $\mathrm{N}-\mathrm{H}, \mathrm{C} \equiv \mathrm{N}$, and $\mathrm{C}=\mathrm{C}$ linkage, respec- 
Table III. Results of polymerization of $\mathbf{2}$ with diphenols and diamins in the presence of DABCO

\begin{tabular}{clcccc}
\hline Polymers & \multicolumn{1}{c}{ Monomers $^{\mathrm{a}}$} & MW/ $\times \mathbf{1 0} 0^{-4 \mathrm{~b}}$ & MWD & $\eta_{\text {inh }}{ }^{\mathrm{c}}$ & Yield $\%$ \\
\hline $\mathbf{8}$ & BPA & 1.05 & 1.8 & 0.31 & 86 \\
$\mathbf{9}$ & BPA+1,3-BHPP & 1.47 & 1.7 & 0.41 & 92 \\
$\mathbf{1 0}$ & HQ+1,5-BAPP & 2.10 & 1.5 & 0.59 & 94 \\
$\mathbf{1 1}$ & ODA+BPA & 1.98 & 1.6 & 0.58 & 91 \\
$\mathbf{1 2}$ & ODA+1,5-BHPP & 2.23 & 1.9 & 0.62 & 96 \\
$\mathbf{1 3}$ & AP & 1.25 & 1.8 & 0.32 & 89 \\
\hline
\end{tabular}

${ }^{a}$ BPA, bisphenol A; 1,3-BHPP, 1,3-bis(4-hydroxyphenoxy)propane; HQ, hydroquinone; 1,5-BAPP, 1,5-bis(4-aminophenoxy)pentane; ODA, 4,4'-oxydianiline; 1,5-BHPP, 1,5-bis(4-hydroxyphenoxy)pentane. ${ }^{\mathrm{b}}$ Molecular weights were measured with Waters HPLC using three columns $\left(3,4\right.$, and $5 \AA$ ) by using THF as eluent at $30^{\circ} \mathrm{C}$. ${ }^{\mathrm{c}}$ Inherent viscosity was determined by Cannon-Ubbelode viscometer in $1.0 \mathrm{~g} \mathrm{dL}{ }^{-1}$ in $\mathrm{DMF}$ at $20^{\circ} \mathrm{C}$.

Table IV. Thermal properties of polyenaryloxynitriles and poly(enamino-enaryloxynitriles)

\begin{tabular}{|c|c|c|c|c|c|c|c|c|}
\hline \multirow{2}{*}{ Polymers } & $T_{\text {exo }}^{a}$ & $T_{\text {endo }}^{\mathrm{b}}$ & $T_{\mathrm{g}}^{\mathrm{c}}$ & $T_{10 \%}{ }^{\mathrm{d}}$ & \multirow{2}{*}{$\frac{\text { Gel Fraction }^{\mathrm{e}}}{\%}$} & \multicolumn{3}{|c|}{ Residual Weight/\% } \\
\hline & \multicolumn{4}{|c|}{${ }^{\circ} \mathrm{C}$} & & $400^{\circ} \mathrm{C}$ & $500^{\circ} \mathrm{C}$ & $500^{\circ} \mathrm{C}^{\mathrm{f}}$ \\
\hline 7 & 338 & 203 & - & - & 72 & 82 & 71 & - \\
\hline 8 & 248,344 & - & - & 426 & 91 & 92 & 86 & 91 \\
\hline 9 & 349 & - & 251 & 389 & 89 & 88 & 72 & 78 \\
\hline 10 & 351 & - & 249 & 424 & 92 & 95 & 87 & 94 \\
\hline 11 & 342 & - & - & 499 & 94 & 93 & 90 & 95 \\
\hline 12 & 352 & - & 232 & 428 & 91 & 92 & 83 & 88 \\
\hline
\end{tabular}

${ }^{\mathrm{a}} T_{\text {exo }}$ : temperature of exotherm. ${ }^{\mathrm{b}} T_{\text {endo }}$ : temperature of endotherm. ${ }^{\mathrm{c}} T_{\mathrm{g}}$ : glass transition temperature. ${ }^{\mathrm{d}} T_{10 \%}:$ temperature determined at a weight loss of $10 \%$. ${ }^{\mathrm{e}}$ Gel fraction obtained by heating the samples at $330^{\circ} \mathrm{C}$ for 30 min. ${ }^{\mathrm{f}}$ Residual weight of cured polymers at $330^{\circ} \mathrm{C}$ for $30 \mathrm{~min}$.

tively. In the cases of polymer 10, 11, and 12, the characteristic aliphatic $\mathrm{C}-\mathrm{H}$ absorption bands were exhibited at $2860-2920 \mathrm{~cm}^{-1}$. In the ${ }^{1} \mathrm{H}$ NMR spectrum of polymer 10, aromatic protons in the fragment of phenyl proton of 2 appeared at $7.6 \mathrm{ppm}$ and the aromatic protons in bisphenol A and ODA units appeared between 7.2-6.8 ppm as multiplet peaks. The chemical structure of $\mathbf{1 3}$ containing enamino-enaryloxynitriles was identified by IR and ${ }^{1} \mathrm{H}$ NMR spectrum, giving characteristic absorption bands and peaks analogous to polymers 10-12.

The solubility of the polymers was tested in various solvents such as $N, N$-dimethylformamide (DMF), $N, N$ dimethylacetamide (DMAc), NMP, acetonitrile, THF, acetone and ethanol. The polymers were soluble in common organic solvents including THF and pyridine as well as typical polar aprotic solvents such as DMF and NMP. Bulky and polarizable dicyanovinyl groups seem to result in good solubility. They displayed virtually no solubility in ethanol. The copolymer $\mathbf{9}$ derived from bisphenol A and 1,3-BHPP showed better solubility than 8 derived from rigid aromatic diol. Higher solubility was associated with alkyl units, which enhanced the flexibility of macromolecular chains. The solubility of $\mathbf{1 1}$ and 13 derived from bisphenol A and ODA was somewhat different from that of $\mathbf{1 0}$ and $\mathbf{1 2}$, and this may be attributed to the aliphatic units.

Polymers obtained from solution polymerization had inherent viscosity of $0.31-0.62 \mathrm{dL} \mathrm{g}^{-1}$. Average molecular weights obtained from soluble portion in THF were $10500-22300$.

DSC data of polyenaryloxynitriles and poly(enaminoenaryloxynitriles) are summarized in Table IV. The polymers displayed no endothermic peak. The exothermic peak presumably derives from the cross-linking reaction of dicyanovinyl group and spans $310-350^{\circ} \mathrm{C}$ as

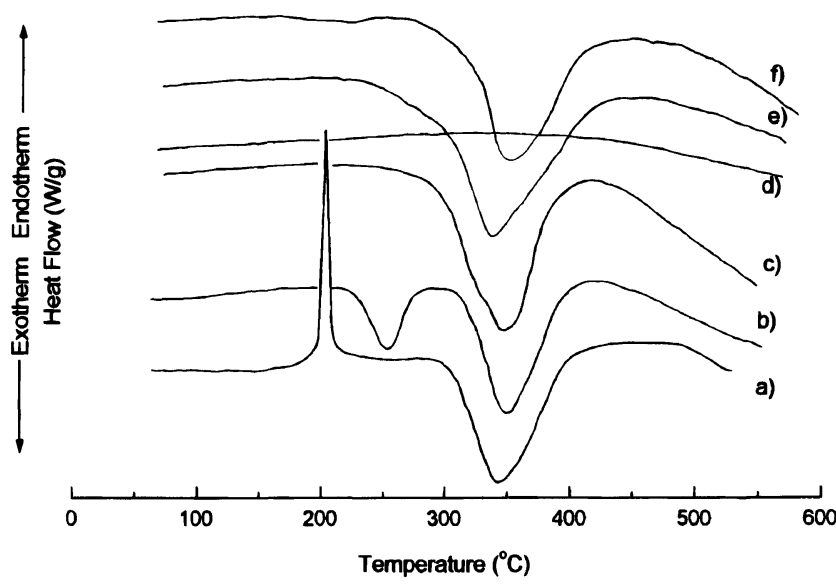

Figure 3. DSC thermograms of a) model compound $\mathbf{7}$, b) $\mathbf{8}$, c) $\mathbf{1 1}$, d) 11 (2nd scanning), e) 13 and f) 12 at a heating rate of $10^{\circ} \mathrm{C}$ $\min ^{-1}$ in nitrogen.

shown in Figure 3. The onset of the curing exothermic transition and maximum temperature of the exotherm follow similar trend regardless of the chemical structures of the polymers.

The functional roles of enaminonitriles and enaryloxynitriles for curability were estimated by comparing polymers 8, 9, and 13 with model compounds 7. Poly(enamino-enaryloxynitriles) possessed enaminonitriles and enaryloxynitrile groups, each of which may be curable by similar mechanism. Polymers may perhaps be made to react with either enaryloxynitrile or enaminonitrile groups. The second run, when the first heating was stopped at $340^{\circ} \mathrm{C}$, measured at the same heating rate for sample 11 showed no exothermic peak as shown in Figure 3d. Further cross-linking of the dicyanovinyl group 


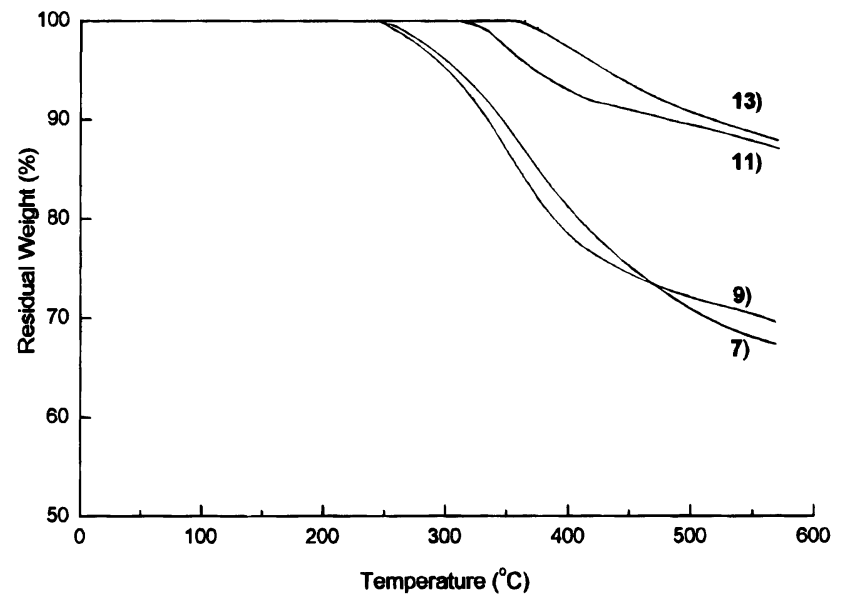

Figure 4. TGA thermograms of model compound $\mathbf{7}$, polymers $\mathbf{9}$, 11 , and 13 at heating rate of $10^{\circ} \mathrm{C} \mathrm{min}-1$ under nitrogen.

may thus not occur. No cured samples redissolved completely in DMF and NMP, which are good solvents for oligomers. The cured polymers showed gel fractions from 89 to $94 \%$.

IR spectroscopy was used to follow thermal curing of a sample on $\mathrm{KBr}$ salt plate. IR spectra showed a spectral change after curing of polymers. A strong absorption band at $1450-1650 \mathrm{~cm}^{-1}$ indicates the presence of $\mathrm{C}=$ $\mathrm{N}$ linkages formed during curing. The intensity of the nitrile band around $2220 \mathrm{~cm}^{-1}$ decreased. Changes in IR spectra are consistent with intermolecular cross-linking of dicyanovinyl groups proposed previously., ${ }^{5,13}$ In the case of polyenaminonitriles, the dicyanovinyl group is consumed in intramolecular cyclization. ${ }^{5}$ The thermal stability of polymers containing enaryloxynitriles group is probably enhanced through intermolecular crosslinking. ${ }^{10,13}$

Thermal stability data are listed in Table IV. TGA thermograms shown in Figure 4 are characterized by shallow weight loss followed by a gentle degradation peak. Polymers 8,11 , and 13 were stable up to $350^{\circ} \mathrm{C}$ under nitrogen as determined by thermogravimetric analysis. Degradation starts around $350^{\circ} \mathrm{C}$ with $10 \%$ weight loss above $400^{\circ} \mathrm{C}$ for all samples irrespective of the chemical structures of polymers. The lowest initial decomposition temperature (IDT) and residual weight were exhibited by polymer $\mathbf{9}$.

The polymers with rigid aromatic units gave residual weight from $86 \%$ to $91 \%$ at $500^{\circ} \mathrm{C}$ at a heating rate of $10^{\circ} \mathrm{C} \min ^{-1}$ in nitrogen and sustained a $10 \%$ weight loss around $429-515^{\circ} \mathrm{C}$. Anaerobic char yields of these thermally treated poly(enamino-enaryloxynitriles) depended on backbone structures. Polymer 13 containing aromatic units, has been found the most thermally stable compared to other precursors and about $91 \%$ residual weight has been observed at $500^{\circ} \mathrm{C}$.

Thermal properties of cured polymers at $330^{\circ} \mathrm{C}$ for 30 min compared with those uncured were improved for all polymers in Table II.

Thermal stability of polymers is similar to that of corresponding polyenaminonitriles and polyenaryloxynitriles between 400 and $500^{\circ} \mathrm{C}$, as previously reported. ${ }^{6,14,15}$

In conclusion, poly(enamino-enaryloxynitriles) containing enaryloxynitriles and enaminonitriles units were synthesized by solution polymerization. They generally showed crosslinking exotherms around $340^{\circ} \mathrm{C}$ and thermal stability with a $77-92 \%$ residual weight at $500^{\circ} \mathrm{C}$ under nitrogen.

Acknowledgments. This work was supported by Korea Research Foundation Grant KRF-1999-015-DP 0208.

\section{REFERENCES}

1. L. Pauling, J. Am. Chem. Soc., 54, 3570 (1932).

2. K. Friedrich, Angew. Chem. Int. Ed., 6, 959 (1967).

3. K. Wallenfels, K. Friedrich, J. Rieser, W. Ertel, and H. K. Thieme, Angew. Chem. Int. Ed., 15, 261 (1976).

4. Z. Rappoport and B. Avramovitch, J. Org. Chem., 47, 1397 (1982)

5. Z. Rappoport and A. J. Topol, J. Chem. Soc., Perkin Trans. 2, 863 (1975).

6. Z. Rappoport and R. Ta-shma, J. Chem. Soc. Sect. B, 1461 (1971).

7. Z. Rappoport and R. Ta-shma, J. Chem. Soc. Sect. B, 871 (1971).

8. Z. Rappoport and A. J. Topol, J. Chem. Soc., Perkin Trans. 2 , 1823 (1972).

9. A. D. Josey, C. L. Dickinson, K. C. Dewhirst, and B. C. Mckusick, J. Org. Chem., 32, 1941 (1967).

10. C. L. Dickinson, D. W. Wiely, and B. C. Mckusick, J. Am Chem. Soc., 82, 6132 (1967).

11. M. S. Gong and H. K. Hall, Macromolecules, 20, 1464 (1987).

12. D. R. Robello and J. A. Moore, Macromolecules, 22, 1094 (1989).

13. M. S. Gong, S. T. Kim, and H. S. Moon, Makromol., Chem Rapid Commun., 12, 591 (1991).

14. H. G. Cho, S. H. Choi, and M. S. Gong, Macromolecules, 26 , 6654 (1993).

15. H. S. Moon, J. S. Kim, C. B. Kim, and M. S. Gong, Polym. J., 25, 193 (1993).

16. J. C. Shin, T. M. Kim, and M. S. Gong, Macromolecules, 28 $2212(1995)$.

17. J. H. Ha, C. Kim, and M. S. Gong, Polym. J., 27, 536 (1995).

18. S. H. Moon, S. G. Kim, T. M. Kim, and M. S. Gong, Bull. Ko rean Chem. Soc., 15, 901 (1994).

19. S. G. Kim, Y. K. Han, and M. S. Gong, Bull. Korean Chem. Soc., 16, 326 (1995).

20. N. Kim and M. S. Gong, Bull. Korean Chem. Soc., 21, 1111 (2000).

21. A. C. Griffin and S. J. Havens, J. Polym. Sci., Part B: Polym. Phys. Ed., 19, 951 (1981). 